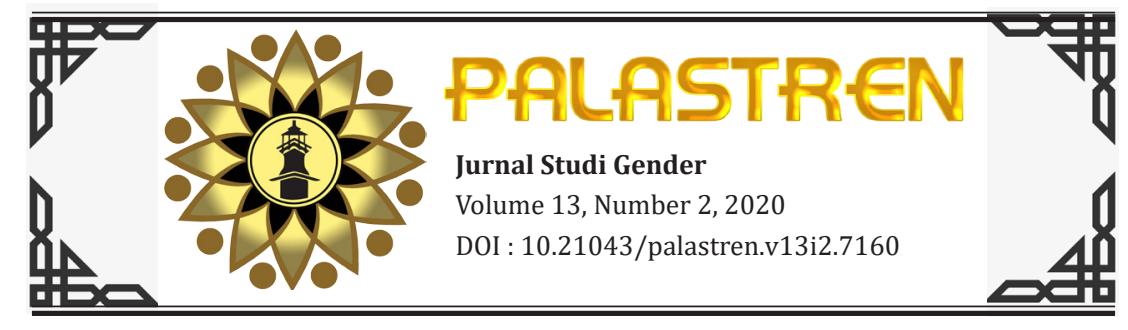

\title{
GENDER EQUALITY ON NAHDLATUL ULAMA AND MUHAMMADIYAH PERSPECTIVE
}

\author{
Dewi Ratnawati
}

Ahmad Zainal Abidin

Taufiqurrohim

Thoriqul Aziz

\author{
Institut Agama Islam Negeri Tulungagung \\ Dewira27@yahoo.com; ahmadzainal7474@gmail.com \\ taufiqurrohim@mail.ugm.ac.id; thoriqulaziz11@gmail.com
}

\section{Abstract}

Factors related to the discrimination of women's rights include religious perspectives that are contaminated by cultural patriarchy, race, social strata, gender identity, sexual orientation, age, and health. Liberation of women's rights can be realized by Islamic organizations which are free from the negative influence of patriarchal culture. These organizations are Nahdatul Ulama 'and Muhammadiyah. These two mass organizations were chosen because they have the largest adherents and have a strong influence on the development of Islam in Indonesia which has different ideological tendencies. The focus of discussion includes not only Nahdatul Ulama and Muhammadiyah gender perspective, but also Nahdatul Ulama' and Muhammadiyah gender equality perspective. The method used by the author is a library research. Sources of data taken are in the form of the results of the congress decisions of the two mass organizations as well as the relevant literacy themes. This research shows, although the two organizations have different ideologies, they both have similarities in gender thinking. This is proven by several studies on the existence 
of granting freedom for women to realize their rights and potentials in both the public and domestic sectors.

Keyword : Gender; Nahdatul Ulama'; Muhammadiyah.

\section{Abstrak}

Faktor-faktor yang terkait dengan diskriminasi hak perempuan meliputi sudut pandang agama yang terkontimasi oleh cultural patriarki, ras, strata sosial, identitas gender, orientasi seksual, usia, serta kesehatan. Pembebasan hak perempuan dapat direalisasikan oleh organisasi Islam yang terbebas dari pengaruh negatif budaya patriarki. Organisasi tersebut tidak lain yaitu Nahdatul Ulama' dan Muhammadiyah. Kedua ormas ini dipilih, karena memiliki penganut terbesar dan memiliki daya pengaruh yang kuat dalam perkembangan Islam di Indonesia yang memiliki kecenderungan ideology yang berbeda Fokus pembahasan meliputi gender perspektif Nahdatul Ulama', gender perspektif Muhammadiyah, dan gender equality perspektif Nahdatul Ulama' dan Muhammadiyah. Metode yang digunakan penulis berupa library research. Sumber data yang diambil berupa hasil-hasil keputusan muktamar kedua ormas serta literasi-literasi yang relevan dengan tema. Penelitian ini menunjukan, meskipun kedua ormas meiliki ideology berbeda, namun keduanya memiliki kesamaan dalam pemikiran gender. Hal ini terbukti dengan beberapa kajian tentang adanya pemberian kebebasan bagi perempuan untuk merealisasikan hak dan potensi yang dimilikinya baik dalam sektor publik maupun sektor domestic.

Kata Kunci: Gender; Nahdatul Ulama'; Muhammadiyah.

\section{A. INTRODUCTION}

Human was created by God with the same degree and rights. Distinction in human lies in the biological field. As a glorified being of God, humans are required to carry out all of God's commands without having to see biological existence. The obligations that God has placed to the humans are worship, harmonious socialization with their communities, survival, and education. Humans realize these four points as God's creatures 
which are given the advantage of intelligence. Granting equal rights to humans as a form of that, God does not isolate or discriminate against humans as His servant. For this reason, as beings who are glorified from other creatures of God, humans have the free right to develop their existences.

The development of self-existence can be realized by expanding knowledge where humans do lifelong education. Specific things in human education are social interactions because social interaction formed in harmony can escalate knowledge, self-potential, creativity and self-innovation, as well as customs that grow in the community. In this case, humans are required to be very clever to collaborate with other human beings as an effort to defend themselves in the midst of a society that has a various organizations and cultures.

Organization and culture are forms of social interaction that develops in the midst of community life because all the rules in the organization are controlled by the culture created by the community itself. The function of culture is to regulate people in order to understand and comprehend how to behave and act for their survival (Wahyuni, 2018: 46). In accordance with the review of this function, most people make different rules regarding to grant the rights between men and women. For people who follow the modern style, these rights are not based on biological forms but according to the skills they have. Whereas for people who still hold traditional customs, the distinction of rights is very clear that women do not have equality with men both in the leadership and the skills they have.

Achie (2014: 204) other factors related to discrimination of women's rights include religion or belief, race, status, caste, gender identity, class, sexual orientation, age, and health. These factors make women do not have the opportunity to develop the skills they have. So that the paradigm of men against women is nothing but it is a complementary creature of survival for men. 
Triggering the emergence of discrimination and isolation of women's rights, there are needs to be intensively handling the role of Islam in organizations that are controlled by culture that has a negative influence on gender equality for women. One role for the form of Islam can be in the form of giving freedom to women's rights as long as they do not violate their nature as women. One example is the role of women in the time of the Prophet. Around 50 women took part in the Hadith narrator (rawi). Likewise, Aisha as the wife of the Messenger of Allah played a role in politics. This was proven when Ayesha took part in the Uhud war (Ruminiati, 2016: 82).

Related to the above review, the good organizations are organizations that uphold religious values as the norm that provide equal justice for human rights in accordance with gender equality between men and women where They have the same rights as men in education, knowledge expansion, skill escalation, leaders, and politics. The granting of equal rights to women is one manifestation of freedom for women from discrimination and isolation that has shielded them.

According to the results of previous studies, Islam teaches humans to be virtuous, respecting others, and tolerance. One manifestation of religious obligations is to provide equal rights to women. This is realized as an effort to improve the standard of living of women by building education, health levels, involving women in contributions as individuals, citizens and community members. Conversely, the behavior of discriminating against others and not respecting individual rights is strictly prohibited and considered as a cruel act by religion (Ichsan, 2014: 66).

Studies that are relevant to this research can be seen in the papers produced, such as the work of Martin Van Bruinessen (1994) entitled "NU Tradisi, Relasi-Relasi Kuasa, Pencarian Wacana Baru" which talks about NU's relationship with the ruling government in Indonesia from time to time. In the other hand, Siti Syamsiyatun, “Muslim Women's Politics in Advancing 
Their Gender Interests: A Case-Study of Nasyiatul Aisyiyah in Indonesian New Order Era. In this study, Syamsiyatun examines the activities and strategies of Muhammadiyah Muslim youths who are members of the Nasyiatul Aisyiyah community. This mass organization developed the importance of paying attention to gender in the New Order era (1966-1998). Their struggle was successful in negotiating orders at that time that guaranteed positions for the benefit of women (Syamsiyatun, 2007: 57)

Siti Ruhaini Dzuhayatin's doctoral dissertation conducted from 2005-2011 entitled "Rezim Gender Muhammadiyah: Kontestasi Gender, Identitas, dan Eksitensi". In this study, Dzuhayatin has a fundamental question about whether the modernity or progress of Muhammadiyah goes hand in hand with modernity, including the gender regime. Second, as a modern organization, where is the position of Muhammadiyah in the contestation of local, national and international gender regimes in historical events. From this question, Dzuhayatin found that there was a decline in gender views in Muhammadiyah, from progressiveism to conservativism. This is due to a shift in leadership and socio-politics outside Muhammadiyah (Dzuhayatin, 2015: vi).

Meanwhile, with a different focus, the study of gender issues in NU was reviewed by Jamal Ma'mur in his doctoral dissertation entitled "The Dynamics of Gender Thought in Nahdlatul Ulama (Decision Study of the 28th Nahdlatul Ulama Congress [1989] to the 32nd Nahdlatul Ulama Congress. [2010]". In this dissertation, Ma'mur discusses gender thinking which is limited to the decisions of the 28th Congress to the 32nd Congress. This dissertation discusses six gender issues, including interfaith marriage, mut'ah marriage, women working at night outside the home, women's leadership, trafficking, and female circumcision. From the results of his study, Ma' mur got the dynamics of gender thinking in NU which were divided into three actor typologies, which are: conservative groups who maintain traditions rigidly 
with textual understanding, moderate groups who are responsive to the dynamics of the times with contextual understanding, and liberal groups who carry justice of gender with a rational and deconstructive understanding (Ma'mur, 2014: 3).

From the various studies above, it only focuses on each of the mass organizations and it is not clear that there is a comparison between the two. Even though these two mass organizations have had a significant influence on the development of Islam in Indonesia, the tendency of different ideologies is that these two mass organizations are often seen as antithesis to each other. Starting from here, it is interesting to study more deeply related to the problems of concern between the two mass organizations, gender is one of them. The author chose these two mass organizations because, 1 ) both mass organizations have the largest adherents in Indonesia, 2) both mass organizations pay great attention to gender issues.

Enforcement of justice against women is one of the discussions for the author to the further exploration of gender equality such as the results of the decisions of the second congress of organizations and studies that are relevant to the research theme.

For this reason, theauthor raises the theme of gender equality in the perspective of Nahdatul Ulama 'and Muhammadiyah. The method used by the writer is a library research. Sources of data are taken from the relevant theme raised by the author. So the data source can be proven by its validity and accuracy.

\section{B. DISCUSSION}

\section{Definition of Gender and Mass Oragnizations}

Literally, gender has the same meaning as sex, namely gender. However, conceptually, according to the feminist view, this understanding is different. Gender is something that cannot be changed, because it is the nature of the Almighty. While gender 
is a trait inherent in both men and women which is formed from constructs through socio-culture. So, it does not include the natural. Examples of gender traits can be seen from the meekness, patience, emotional beauty, and stubbornness of a woman. Meanwhile, men are created with strong, rational, mighty, male characteristics, and so on. This difference between men and women is formed in a very long process (Ilyas, 2005: 14).

There are many theories about gender, including: first, the theory of psychoanalysis which suggests that gender differences are caused by psychological factors. Second, the structural functionalist theory which argues that gender is caused by functionalists between men and women. Third, conflict theory argues that gender is caused by the oppression of the ruling class. Fourth, the socio-biological theory which makes gender differences a result of a mixture of social and biological factors. Female reproduction is considered a barrier to balance male power (Ilyas, 2005: 16-17). It is from these several theories that the occurrence of gender differences in human history.

Meanwhile, mass organizations stand for community organizations. An organization appears there is usually pressure. The occurrence of acts of justice and discrimination wants to make a change. Therefore, this movement organized power by recruiting potentials to match a power that came from outside. Thus, the emergence of this organization will be a concern and be taken into account by other parties. There are many kinds of mass organizations that have emerged in Indonesia, among these organizations that have emerged are broadly divided into modernist and traditionalist mass organizations. Modernist mass organizations emerged as a result of the attitudes of superstition, heresy, and churafat (TBC) that were spread throughout society. Meanwhile, mass organizations from traditionalist circles emerged as anti-modernists' thesis. Among the mass organizations of the two groups, such as: Sarikat Islam, Perti, Muhmmadiyah, NU, alIrsyad, al-Washliyah, and so on (Ghafur, 2012: 4-6) 


\section{Gender Perspective Nahdatul Ulama'}

Gender related issues are not taboo for the community. Changes in society's mindset which are influenced by modernization and technological sophistication have made society as citizens who uphold human values and freedom in realizing individual rights. Even though there are still some strongholds of society that still hold patriarchal culture. It is happen in open society, people who ignore the distinction of rights. For the most important community, welfare of the people lies in freedom as citizens in participating and advancing programs that have been planned by organizations that are in the community.

One organization that opens the door to gender existence is Nahdatul Ulama '. It cannot be denied that the law made by the Nahdatul Ulama organization 'is very conservative on gender issues. Along with the development of technology and civilization, the era has changed the mindset of people who are sustainable in the organization Nahdatul Ulama 'responding to gender issues. Evidence of NU's openness to gender issues was recorded in the results of the National Conference, Congress and Big Conference decisions. Decisions made in the form of decisions that uphold the benefit of the community both contextually and dynamically (Ma'mur, 2015: 40).

Urgency of Nahdatul Ulama organization 'is a community that upholds the values of justice and benefit. Activities that have emerged in the Nahdatul Ulama organization 'include P3M (Center for Pesantren and Community Development) which has activities to drive the women's fiqh program (fiqh an-nisā ) ) around the 90s. This activity was later developed by Rahima, an NGO (non-governmental organization) that was born from the P3M fiqh an-nisa division. The study was initiated by young NU kiai, such as KH. Husein Muhammad. This activity then spread to Fatayat, which conducted a gender study in 1990 and was followed by IPPNU by pioneering a study of strengthening 
women's rights (empowering women) in 1996. Then in 1998, which was known as the reform era in Indonesia, women began to be taken into account along with Megawati Soekarno Putri and Siti Hardiyanti Rukmana (Mbak Tutut) as the leader of the country. (Ma'mur, 2014: 38-39).

The activities formed in the group were mostly women who participated. The active role of women and men in the group has gender equality. There is no distinction, discrimination, or isolation. Manifestation of gender equality is based on religious teachings both originating from the Qur'an and Al-Hadith. Decision-making that originated in the Hadith as what was surveyed by Aisha when face women in Sham from Hamas. One of the women who firm in making decisions was none other than Aisha when facing problems related to women bathing in public baths. Then Aisha approached them by exclaiming that. According to the Apostle's words, the veil of closure can be opened between God and His servant (woman) lies in the behavior of women who take off their clothes other than in her husband's house (Nafriandi, 2015: 140-141).

A review of the policies realized Aisha's wisdom above is evidence that women have a right to share in all fields, especially in the legal field. Besides being an expert in the field of law, Aisha was also an expert in the fields of medicine and war. Aisha's expertise in various fields of science never received a response from the Prophet. Whatever is realized 'Aisha as long as it does not conflict with religious law, the Messenger of Allah always supports it. The support given by the Messenger of Allah to Aisha was proof that there was no scientific distinction caused by human biological form factors.

Related to the above review with the decision made by Nahdatul Ulama, 'it has a significant correlation. Distinction between women has never existed. As the example 'Aisha above, the policies are related to decisions of Muktamar, Big Conference (Konbes), and Natioal Conventions regarding gender issues. 
Decisions and gender issues in NahdatulUlama' includeinterfaith marriages, women who work at night, mut'ah marriages, female leaders, and female circumcision. Related to these gender issues, the decision making determined by Nahdatul Ulama 'is more on the welfare, prosperity, and prosperity of the people.

\section{a. Women's Leader}

The role of women as leaders in the country raises a variety of assumptions from the community both assumptions in the positive realm and in the negative realm. The rise of discourse related to women leaders in various sectors of the country, arousing the role of scholars' to conduct legal studies related to the role of women as leaders. In addition to take a part in the household sector, women have great potential stored in themselves as leaders to advance and develop the nation and state. Facts regarding women leaders have been realized in Indonesia. Some examples related to women leaders include the East Java governor leader, none other than women, the RI presidential position after the end of Gus Dur was taken over by female leaders, and the Mayor of Surabaya related leaders were taken over by women. The surge in women's leadership has a positive impact on the progress and development of the country.

In accordance with the decision of the Alim National Conference on 16-20 Rajab 1418 H / 17-20 November 1997, at Qomarul Huda Bagu Islamic Boarding School, Pringgarata Central Lombok, West Nusa Tenggara, about Masail Diniyah Maudhu "iyyah. In this congress, NU decided to give women the same rights as men to serve religion, the country, and the nation and state in line with the demands of Islam itself. NU recognizes that women and men have the same and equal rights (Azca. et. al, 2019: 143). The Ulamas of NU agreed that women have the right to implement their rights as leaders. This 
is in accordance with the foundations in the Qur'an and Al-Hadith. Islam gives equal rights between women and men both in devoting themselves to homeland, nation, and religion. Women get a noble position in the teachings of Islam. Only the location of distinction to women so far is not due to religious teachings but rather the influence of patrilineal culture which has an impact on the discrimination of women's rights. Patriarchal culture has a strong dominance in its specific society in East Java. This slows down the realization related to justice, harmony and prosperity of the people (Mufidah, 2017: 463). So women are seen as weak and cannot contribute to the progress of the nation and state.

The presence of female scholars in various fields provides an advantageous position regarding the affirmation of female' scholars in patrilineal culture. The fields occupied by women as Ulama 'include pesantren, majelis taklim, reading, television channels with a female audience. Muslim women can be consultants for women, especially scholars. As agents of propagation of Islamic da'wah, women are preferred to their community because they are considered capable of understanding women's hopes, desires, and ideals (Yanuardi, 2018: 25).

Nahdatul Ulama provides facilities related to Islamic symbols for Ulama for women. Provision of facilities to female ulama is a manifestation of openness to the existence of women in upholding the teachings of Islam. The function of women in Islamic symbols has an urgency that can direct women to behave in accordance with values, norms, which are set by religion. Changes in women's behavior are caused by freedom of consultation without any distance limiting clients from consultants. So the intervention of Ulama women has a big influence on the existence of their community towards true Muslim women. 


\section{b. Female Circumcision}

Concerning the issue of circumcision for women resulted in a heat debate between the Ulama NU and Fatayat group. The debate that took place in the PreCongress (32nd Congress in Makassar) forum was motivated by gender issues that emerged at that time. Fatayat members argue that the realization of circumcision for women as an act violates decency because circumcision can have infection implications for the female vagina. The tools used are not sterile. On the contrary, the viewpoint of the Ulama NU argues that circumcision for women must be realized as kitan for men.

The debate between the two camps under the umbrella of the Nahdatul Ulama Organization 'cannot be stopped, so this has prompted two female leaders to reduce the problem of the circumcision debate for women. The two figures provide a middle ground by involving the health department officials to take part in the realization of circumcision for women by accompanying and conducting intensive counseling instead of stopping the practice of circumcision whose realization is based on Islamic religious teachings (Ma'mur, 2015: 235).

The highly debate between the two camps within the Nahdatul Ulama organization 'was finally brought down although there is one faction still feels discriminated by the results of decisions related to the heated debate. The presence of conflict within the organization is an art that can illustrate the spirit and motivation in advancing and developing the organization. This is the duty of provocateurs to ignite the fire of enthusiasm in the organizations they foster. Without the presence of conflict, an organization will experience retardation and slump which ended in a rift. The biggest wisdom of the emergence of controversy related to female circumcision 
can open a new window for the Nahdatul Ulama organization to deepen the law regarding the study of circumcision for women.

The circumcision review for women above requires a study of illat related to the law. This can be realized in terms of medical, sociological, historical, anthropological, and interdisciplinary studies. So this can bring up the law that leads to the benefit of the people both based on the hadith and the Qur'an in contextual and textual terms because the practice of circumcision in each region has a more specific distinction. So this has led to controversies from radicals, moderates, classics, and scholars (Agus, 2016: 291).

This issue was raised in the 32nd Congress in Makassar which decided that the law of circumcision for women was permissible. In other hand, men are more recommended. Meanwhile, it is related to the ability to announce it in the wider community. Men who are circumcised are encouraged to disseminate the news, such as in the form of a walimatul khitan (circumcision event) invitation, while for women on the contrary, it must be kept secret and do not need to be exposed (32nd NU Congress 234: 2010).

Distinctions of circumcision practices for women often cause problems in the community although the actual problems that have arisen can be suppressed and minimized. For people who have a firm stand on the basics of religion and correlate with the facts, the problem that arises is only art for the community. Conversely, for people who assume without correlating legal theory with reality, most of them are shackled by lust that leads to politics in the name of religion. 


\section{c. Women Work Nighttime Professions}

Previously, earning a living for the family was a male profession as head of the household. Along with the development of the civilization of the times, women also take part in finding good fortune for their families. The emancipation movement which is realized by women is a manifestation of that. Women do not want to always depend on their husbands. Women's freedom in developing skills to earn a living is not a place to compete or want to be superior to men because true self woman only wants her existence to give benefit to others, especially the men. The emancipation movement is realized by women with the aim of helping the family economy and making themselves independent individuals.

Empowering women to become educated people in the economic field is an indicator that manifests the level of welfare in realizing their rights and having freedom of work. So they make their selves independencies and have an income. There are two perspectives regarding women's work in the public world (Amany, 2018: 100). The first is a career woman. The second is working women (Nasaruddin, 2014: 247). Women have more careers in the realm of income seeking, escalating and expanding their self-existence with the aim of becoming a center for skills cultivation. On the contrary, working women are more focused on earning income rather than exporting self-excellence.

Women who work more than the limit of working hours or work at night shift often cause problems, both from their families and communities who live near their homes. These problems arise as a result of negative public assumptions about women who work night shifts and women who work above normal hours. The implication of the problem of the rise of women's work has led to the 
Nahdatul Ulama's viewpoint in addressing the problems that have been fluctuating in people's lives.

This problem was studied in the 29th NU Congress in Cipasung, Tasikmalaya on 1 Rajab 1415 H / 4 December 1994. The Nahdatul Ulama's viewpoint is classified into three. Firstly, the law is permissible if the woman gets permission from her family, husband, guardian and her occupation does not bring harm to herself or others. Secondly, the law is haram if the work carried on by the woman brings harm to herself and others who live near her residence. Thirdly, the law is makruh if the work occupied by women is feared to bring harm (Ma'mur, 2015: 194-195).

According to the results of the study, women may work to take night shifts if they fulfill eight conditions, namely maintaining their views, dressing according to the teachings of Islam, getting permission from family, not leaving obligations at home, avoiding slander, occupation does not impose dignity on men, does not tabarruj, and not secular (Muhibuddin, 2018: 146-150). The eight conditions are an alternative for women in realizing their role in the economy. Ideal woman and skilled woman are in minute time. So it does not leave its obligations and roles as women.

\section{d. Marriage Mut'ah}

Alternative to distance themselves from adultery relationships, most humans manifest relationships through marriage ties. With the bond of marriage, humans are kept away from misdirection, sexual harassment, acts that do not reflect decency, and form of sakinah, mawadah, and warahmah relationship. But in reality, not all relationships through marriage ties can manifest sakinah, mawadah, and warahmah relationships. One 
example is mut'ah marriage. The first part to suffer losses due to mut'ah marriage is women. The existence of female discrimination due to mut'ah marriage makes other part interest in studying mut'ah marriage as a trending topic on gender issues.

Ma'mur (2015: 202) related to mut'ah marriage, Nahdatul Ulama gave a decision in Bahtsul Masail that, the realization of mut'ah marriage is haram. This issue was raised in the Alim Ulama National Conference which took place at the Qomarul Huda Bagu Islamic Boarding School, Pringgarata Central Lombok, West Nusa Tenggara on 16-20 Rajab 1418 H/17-20 November 1997. This is in line with MUI's decision regarding mut'ah marriage. Mut'ah marriage is included in the classification of haram law because the realization of mut'ah marriage is very detrimental to women. Losses experienced by women includes sexual harassment (women only as objects of male sexual lust), discriminated against women's rights as wives, the fall of the dignity of women as glorified beings, the severance of fathers' obligations to children resulting from mut'ah marriage, and moral grading.

\section{Gender Perspective Muhammadiyah}

Muhammadiyah is an organization that survived for almost a century in the midst of the current cultural, political, economic and social changes that occurred in Indonesia. The birth of the Muhammadiyah organization was influenced by several factors including pressure from western colonialism, cultural ambivalence, traditional feudalism, and religious conservatism. The aim of the Muhammadiyah organization is to present in the midst of society and to finalize the occurrence of religious, social, political, cultural, economic, and manifest disparities in a prosperous and prosperous society (Dzuhayatin, 2015: 40). 
The gap related to the five factors above cannot be separated from the pollen of gender issues. Community response to gender issues is divided into two camps. Firstly, it is in the stronghold of pro-contra. Second, it is the contra stronghold. The viewpoint of the people inside the pro-counter position related to gender issues is more welcome than the people who are in the counter camp. The shallow mindset of people who are counter to gender issues can lead to problems that have implications for the collapse of the Indonesian nation in building a single diversity. The presence of the Muhammadiyah organization in the midst of community disparity is one alternative to finalize the emerging problems. Gender issues that have risen in the midst of community life include the authority of men and women in religion. The ideology of women and men in the family, the dual role of women, and women are as political leaders.

\section{a. Male and female authorities in religion}

Muhammadiyah's perspective on the authority, women and men have equal position because the presence of Muhammadiyah in the midst of community life is nothing but to eliminate discrimination that occurs among fellow Muslims (Muktamar Muhammadiyah ke46, 2010: 22). The welfare of the life of Muslims for the Muhammadiyah organization is more important than raising the authority distinction that can cause social inequality. Community harmony in living life cannot be separated from challenges that arise from within and from outside. The challenge that often arises in the form of a patriarchal paradigm is some people who do not agree with the equality of authority between women and men.

Related to the problem of equality between male and female authorities, Muhammadiyah conducted a study on equality in the realm of religion. The results 
of the Conference's decision in the Tarjih Assembly in 2010 are women can become prayer priests for men if they meet the specified requirements. The conditions include fluent recitation of the Qur' an and the expansion of Islamic religious knowledge that women have beyond doubt (Muktamar Muhammadiyah ke-46, 2010: 238-9). The policy applies to women if there are factors that really need the role of women in realizing Islamic teachings. One example of the phenomenon is related to the role of women as prayer leaders for men if in the region the Muslim minority, and men who embrace Islam are very minimal to the reading of the Qur' an and religious knowledge while the position of women at that time really controlled the shortcomings that exist in men. So this encourages women to take over the prayer for men.

Women's and men's authorities have been reviewed in Islam itself. Islamic teachings give mercy to all of Allah's creations in the universe. Manifestation of His blessings in the form of Islamic confirmation related to equality of women and men as the integrity of humanity (Mayola, 2018: 55). The existence of equality between the authority of women and men functions as a complement to cover the shortcomings of each party. So that the impression of authority in the teachings of Islam is not to overthrow, discriminate, oppress, nor apply dzalim to other human beings but rather, as a relationship that is built on the basis of a bhineka tunggal ika.

Correlation between women and men in a single framework if they can improve the quality of life caused by the diversity of society by expanding the source of cultural knowledge and escalating self-experience. The position of women and men illustrates the whole body part if there is a sick part of the body, other parts of the body also feel pain (Gina, 2015: 36). This is the unity that 
is tucked into the teachings of Islam and is contained in the basis of the state in the second and third precepts which are driven by the first spirit of the precepts. Then, according to the review, male and female authorities in religion do not cause discrimination. Instead religious teachings aspire to the integrity of the correlation between women and men.

\section{b. The Dual Role of Women}

Women are nothing but creatures created by God who have a side of extraordinary beauty in him. In addition to have a gentle heart and attitude, women also have great potential stored in themselves as gifts that God has given them. The great potential that exists in women in the form of women's expertise is in dual roles. Women can play a role as a mother, father, brother, friend, sister, child, sibling, and leader. The toughest role of women when playing a dual role is a mother and father together. On the other hand, earning a living for economic needs and on the other hand guiding, educating children, and taking care of all activities in the household. This hard work can rarely be realized by men because most men are more focused on one role.

According to the Muhammadiyah, women may have careers as long as they are within normal limits. There are several conditions that must be fulfilled by women as a career woman that is not out of the teachings of religion, do not abandon their obligations as a housewife, can maintain personal security, can form a warm correlation in the household and increase faith in God, and the work in which it can benefit the interests of society and religion (Dzuhayatin, 2015: 293-294, Ilyas, 2015: 6-12). Although these five points have been realized by women, women often get insults from the people who 
live around them. Challenges for career-related women can be moral in the form of pressure from the community against the profession.

The above commentary relates to the role of women in business. Furthermore, the role of women is in the field of leaders. Women have advantages over men in leadership, namely women are one step above men in conceptualizing work expectations and are quick to get feedback, women are more ardent in classifying problems and are proven accurate in solving these problems, women are more upholding tolerance as an alternative to prevent opinions becoming distinctive, women are quick to respond to complaints or input from subordinates, women are always open to input that brings goodness to mutual success, women are more sensitive to see subordinates who are less enthusiastic and directly provide motivation and advice that can build the work ethic of their subordinates (Novianty, 2014: 7).

All the roles that are realized by women in their roles as career women, housewives, community members, and leaders while still in Islamic Sharia and fulfill the prerequisites reviewed above. There is no prohibition or law forbidding women to implement all their roles. The superiority of women that does not exist in men in the form of fortitude in dealing with all problems, solving these problems using mother's communication, always optimistic in realizing her dual role at the same time, and having high class enthusiasm and patience in realizing her dual role.

\section{c. Women as Political Leaders}

The role of women as leaders in politics has been realized for a long time. Supporting factors for women's 
existence as a leader include the innovative community environment, openness of the world to female leaders, the existing leader skills within women, support from family and the surrounding environment, changes in community play, education, economy, and cultural civilization changes. These factors make women exist and develop their existence as a leader.

The above commentary is in accordance with the official teachings of Muhammadiyah. Muhammadiyah provides a great opportunity for women to show their existence as specific leaders in politics (Dzuhayatin, 2015: 301). The opportunity provided by the official teachings of Muhammadiyah as proof that, organizations that hold the principles of Islamic teachings will not act ignorantly towards women's human rights because Islam teaches all mankind to uphold justice and not do wrong to both him and others. The prohibition of committing dzalim also applies to the attitude of men to women.

Men and women have the same opportunity to become leaders. There are two things that are considered to be a leader, namely intellectuality and capability (Samsul, 2013: 83). Intellectuality becomes one of the prerequisites for anyone to become a leader. Intellectuals referred to here are more at the level of intelligence of leaders in making plans, making policies, facing challenges and problems that arise both from internal and external sources, experts in the field of strategy, and experts in manifesting social relations. While the points related to capabilities are more pressing on the ability and self-skills that not only accept but also can solve everything that it faces.

Regarding the two points above, the leader prerequisites are not specified to men. The prerequisite applies to anyone who has two potentials (intellectual and capability) has the right to be a leader even if it is a woman. 
Women have the same rights as men to be leaders. As realized by Aisha. Aside from being a leader, Aisha also became a leader in battle. The same right is given by God to women to be a leader with a consequence that all the activities that they realize can be accounted for before God (Raihan, 2015: 627). Carrying the burden of responsibility as a leader is not easy but for women the difficulty does not lie in the responsibilities they carry, but the tyrannical that exists in him as a leader and does not apply the values contained in the basis of religion and state.

An ideal leader is a leader who reflects on the example of the Prophet. As a leader, Rasulullah prioritizes the welfare and safety of his people. This is evident when he breathed his last he was still thinking about the safety and welfare of his people (Sakdiah, 2016: 41). Exemplary of the Prophet as a leader can be used as a reference for female leaders and male leaders. Because leadership is only entitled to be controlled by leaders who uphold the benefit of the ummah, not leaders who are concerned with their personal affairs and are busy in interventions of gender discrimination related to the role and position of women.

\section{d. Women and Men in Family Ideology}

The position of the husband in the household is none other than a leader while women are partners for their husbands, primary madrasah or education for children, and vice leaders in the household. The division of tasks has become an absolute decision that cannot be contested except, the husband has been unable to realize his role as a leader caused by various factors, which are, the husband dies, the husband divorced with his wife, the husband is stricken with a disease that causes the 
body's work system cannot function (paralyzed), as well as a crazy husband. These factors force women to play a dual role as a leader and vice-leader in the household.

The role of women in the family as wives, mothers to children, and community members (Andi, 2015: 189). The role of women as wives includes supporting everything that a husband does, giving constructive input and direction to her husband, creating a harmonious atmosphere and warm correlation in the household, and being able to build and encourage her husband to do positive things. The role of women as madrasah for children includes good role models, providing education in the realm of character formation, providing guidance and direction related to psychological development, and educational language used in the form of mother tongue. The realization of the main madrasah is realized by women as a manifestation to form a young generation of Indonesian people who have high class skills. The role of women as members of the community includes participation in community service, taking part in routine activities that are realized by mothers, and maintaining harmony and harmony in community life.

The results of the research explain that, women do not forget their role as domestic even if they take part in participating in earning a living. For women, their existence in the public sphere is nothing but to cover financial shortages in the household (Annisya, 2018: 194). Smart women are women who can put their positions according to their roles. The multi roles that are realized by women at one time are self-training to become independent individuals. A person who is resilient in facing life's problems, continues to work, and is followed by an optimistic attitude. 


\section{Gender Equality Perspective of Nahdatul Ulama 'and Muhammadiyah}

The decision taken by Nahdatul Ulama 'and Muhammadiyah related to gender issues that, women can realize all their rights as long as they do not violate values and norms in accordance with Islamic law and state law. Both organizations are very enthusiastic about the creativity and active role of women in advancing and developing the country's prosperity. Existence of the role of women is the point of view of the two organizations when it is important in shaping the young generation of the Indonesian nation because the recognition and performance of the child's first character lies in the role of women as mothers.

The role of women in the public and domestic sectors can be realized if there is a specific effort aimed at improving the quality of women's existence and social support. Work performance is in accordance with skill escalation, encouraging women to become qualified and dignified individuals in the public sector (Arbaiyah, 2014: 5). Conversely, the ingenuity and intelligence of women in managing household management can form a harmonious household. The balance between the public and domestic sectors for women can have implications for the well-being of themselves, their families, and society.

Women in the public sector have broad opportunities to show their existence as leaders. The leader referred to here, the leader who not only has the potential to control social interaction but also has the potential to correlate himself with God's existence. This is in accordance with Ali-Imran verse 112. The related commentary on the verse is a balance of correlation between fellow human beings and their Lord as a leader (Tim, 2007: 64). The balance of God's interaction with humans as God's servants can make it easier to achieve all the goals that have been designed. Because humans can only plan and realize what is planned. While the final decision is in the hands of God. 
The equality of Nahdatul Ulama's and Muhammadiyah's decisions regarding the role of women as leaders is that there are no prohibiting laws or prohibitions related to the active role of women as leaders, as long as in realizing their roles women do not depart from religious norms and norms made by the state. The success of the role of women as leaders can be seen from the expansion of the strategies used. Women in realizing their role as leaders by using policies that uphold the values of tolerance, democracy, humanistic, participatory, mutual cooperation, honesty, and three centers of intelligence (Intellectual, Emotional, and Spiritual).

From the explanation above, although the two mass organizations have different ideological tendencies, the thoughts about gender seem to have in common. Gender thoughts in the two mass organizations seem closely related to Islamic feminism. Actually, the Islamic feminism movement is no different from that developed in the West. It is just that in the body of Islam the movement is based on authoritative texts in Islam. The Islamic feminism movement emerged in the 1990s which mostly occurred in the Islamic world. This movement was driven by several figures such as Fatima Mernisi and Nawal Sadawi from Egypt, Amina Wadud Muhsin from America, Zakinah Saadam and Zainah Awar from Malaysia, as well as several feminists from Indonesia such as: Wardah Hafidz, Siti Chamamah Soeratno, Lies Marcoes-Natsir, Siti Ruhaini Dzuhayatin, Zakiah Darajat, Ratna Megawangi, Siti Musdah Mulia, Masdar F. Mas'udi, Budhy Munawar Rahman, Nasarudin Umar (Muqoyidin, 2013: 503-504), KH. Husein Muhammad, and Fakihudiin Abdul Kodir.

The movement run by feminists tries to dismantle and reconstruct gender relations that exist in Islamic sources that cause male domination over women. This is dismantled and reconstructed in accordance with the spirit of Islam which also makes the ideology of liberation for women in line with the ideology of human liberation. From this movement then ideas 
and studies of the interpretation of the verses of the Koran and hadiths carried out by intellectuals. The focus of attention to Muslim feminism is twofold, namely: first, equality between men and women that occurs in the social structure of Muslims due to the existing teachings of Islam, however this male-biased understanding then crystallizes and is considered a standard teaching. Second, in line with this goal, this movement needs to review Islamic sources related to gender relations with a starting point for the basic principles of teaching, justice and equality (Muqoyidin, 2013: 504).

\section{CONCLUSION}

Related to the review of gender issues, the perspective of Nahdatul Ulama includes leaders, circumcision, women's night work professions, and mut'ah marriages. Instead Muhammadiyah's gender issues include men's and women's authority in religion, women's dual role, women as political leaders, and women and men in family ideology. Equality from the perspective of the two organizations is related to gender issues in the form of freedom for women in realizing all their rights as long as they do not violate values and norms in accordance with Islamic law and state law. 


\section{REFERENCES}

Andika, Mayola. (2018). Reinterprestasi Ayat Gender dalam Memahami Relasi Laki-laki dan Perempuan (Sebuah Kajian Kontekstual dalam Penafsiran). Musawa, 17 (2). http:// ejournal.uin-suka.ac.id/pusat/MUSAWA/ article/view $/ 1310$.

Bahri, Andi S. (2015). Perempuan dalam Islam (Mensinerjikan Antara Peran Sosial dan Peran Rumah Tangga). Jurnal AlMaiyyah, 8(2) http://ejurnal.stainparepare.ac.id/index. $\mathrm{php/almaiyah/article/view/321.}$

Djafri, Novianty. (2014). Efektifitas Kepemimpinan Perempuan dalam Karir. Musawa: Journal For Gender Studies, 6(1). http://id.portalgaruda. org/ ?ref=browse\&mod=viewarticle\&article $=295223$.

Dzuhayatin, Siti Ruhaini. (2015). Rezem Gender Muhammadiyah: Kontestasi Gender, Identitas, dan Eksitensi. Yogyakarta: Suka Press UIN Sunan Kalijaga Yogyakarta.

Ghafur, Abd. "Kebangkitan Islam di Indonesia(Telaah Tentang Munculnya Ormas Islam Awal Abad 20 M)", Toleransi: Media Ilmiah Komunikasi Umat Bergama, 4 (2).https:// ejournal.uin-suska.ac.id/index.php/toleransi/article/ view/945.

Hasil-hasil Muktamar 32 Nahdlatul Ulama, (2011). Cet. 2, Jakarta: Sekretariat Jendral PBNU.

Hermanto ,Agus. (2016). Khitan Perempuan Antara Tradisi dan Syari'ah, Kalam: Jurnal Studi Agama dan Pemikiran Islam, 10(1). http://ejournal.radenintan.ac.id/index.php/ KALAM/article/view/343/199. 
Ichsan, Muchammad. (2014). Gender Analysis on Islamic Texts: A Study on Its Accuracy. GJAT, 4(1). file:///G:/gender\%20 scopus/5520140401.pdf.

Ilyas, Yunahar. (2005). Konstruksi Pemikiran Gender dalam Pemikiran Mufasir, Jakarta: Pogram Peningkatan Kualitas Pelayanan Publik Dirjen Bimas dan Penyelenggraan Haji Departemen Agama RI.

-------, Yunahar. “Tajdid Muhammadiyah dalam Persoalan Perempuan". http://tarjih.muhammadiyah.or.id/ download-pandangan-muhammadiyah-tentangperempuan-738.html.

Keputusan Muktamar Satu Abad Muhammadiyah (Muktamar ke -46). (2010). Yogyakarta: Percetakan Muhammadiyah Surya Sarana Grafika.

Lestari, Gina. (2015). Bhinneka Tunggal Ika: Khasanah Multikultural Indonesia di Tengah KehidupanSara". Jurnal Pendidikan Pancasila dan Kewarganegaraan, 28(1). http:// journal.um.ac.id/index.php/jppk/article/view/5437.

Lubis, Amany. (2018). Ketahanan Keluarga dalam Perspektif Islam: Pandangan Komisi Pemberdayaan Perempuan, Remaja dan Keluarga Majelis Ulama Indonesia. Jakarta: Pustaka Cendikianwan Muda.

Ma'mur, Jamal. (2015). Rezim Gender di NU. Yogyakarta: Pustaka Pelajar.

Muhibuddin. (2018). Pandangan Ulama Dayah Terhadap Perempuan Pekerja Pada Malam hari Pada Fasilitas Umum. Gender Equality Internasional Journal Of Child and Gender Studies, 4(1). https://jurnal.ar-raniry.ac.id/index. php/equality. 
Mufidah Ch. (2017). Complexities in Dealing With Gender Inequality Muslim Women and Mosque-Based Social Services in East Jawa Indonesia. Journal of Indonesian Islam, 11(2). mplexities in Dealing with Gender Inequality.

Nafriandi. (2015). Perempuan dan Rasionalitas Penafsiran: Studi Terhadap Penafsiran 'Aisyah RA. Kafa'ah : Jurnal Ilmiah Kajian gender, 5(2). file:///G:/gender\%20scopus/104-3321-PB\%20(1).pdf.

Perumus, Tim. (2007). Al-Qur'an Terjemahan Surat Ali Imran Ayat 112. Bandung: Syaamil Quran.

Prantiasih, Arbaiyah. (2014). Reposisi Peran dan Fungsi Perempuan, Jurnal Pendidikan Pancasiladan kewarganegaraan, 27(1). http://journal.um.ac.id/index.php/jppk/article/ view/5511.

Putry, Raihan. (2015). Kepemimpinan Perempuan dalam Perspektif Islam, Jurnal Mudarrisuna, 4(2). https:// jurnal.ar-raniry.ac.id/index.php/mudarrisuna/article/ view/627/516.

Ruminiati. (2016). Sosio Antropologi Pendidikan Suatu Kajian Multikultural. Malang: Gunung Samudera.

Sudiarti, Achie Luhulima. (2014). Cedaw Menegakkan Hak Asasi Perempuan. Jakarta: Yayasan Pustaka Obor Indonesia.

Syamsiyatun, Siti. (2007 M/1428 H). "MUSLIM WOMEN'S POLITICSIN ADVANCINGTHEIRGENDER INTERESTS: A Case-Study of Nasyiatul Aisyiyah in Indonesian New Order Era", Al-Ja>mi'ah, Vol. 45, No. 1.

Syukur, Yanuardi. (2018). The Riset of Female Ulama in Indonesia: A Gender Perspective. RISEA: Review of Islam in Southeast Asia, 1(1). http://journal.uinjkt.ac.id/index. php/risea. 
Sakdiah. (2016). Karakteristik Kepemimpinan dalam Islam (Kajian Historis Filosofis) Sifat-sifat Rasulullah). Jurnal AlBayan, 22(33). https://jurnal.ar-raniry.ac.id/index.php/ bayan/article/view/636/540.

Suhasti, Ermi. (2018). Polemics on Interfaith Marriage in Indonesia Between Rules and Practices. Al-Jami'ah, 56(2). doi: 10.14421/ajis.2018.562.367-394.

Triana, Annisya dan Krisnani, Hetty. (2018). Peran Ganda Ibu Rumah tangga Pekerja K3L UNPAD dalam Rangka Menunjang Perekonomian Keluarga, Prosiding Penelitian dan Pengabdian Kepala Masyarakat, 5(2). http://jurnal. unpad.ac.id/prosiding/article/view/18370.

Umar, Nasaruddin. (2014). Islam Fungsional: Revitalisasi dan Reaktualisasi Nilai-nilai Keislaman. Jakarta: Elex Media Komputindo.

Van Bruinessen, Martin. (1994). NU Tradisi, Relasi-Relasi Kuasa, Pencarian Wacana Baru, Yogyakarta: LKiS.

Wahyuni. (2018). Agama dan Pembentukan Struktur Sosial:Pertautan Agama, budaya, dan Tradisi Sosial. Jakarta: Prenadamedia Group.

Zakaria, Samsul. (2013). Kepemimpinan Perempuan dalam Persepektif Hukum Islam (Studi Komparatif Antara Pemikiran KH. Husein Muhammad dan Prof. Siti Musdah Mulia) .Khazanah, 6(1). https://journal.uii.ac.id/ khazanah/article/view/3743. 